\title{
The return of the Blue Crab, Callinectes sapidus Rathbun, 1896, after 70 years from its first appearance in the Gulf of Trieste, northern Adriatic Sea, Italy (Decapoda: Portunidae)
}

\author{
Chiara Manfrin $^{1 *}$, Giovanni Comisso' ${ }^{2}$,Andrea dall'Asta ${ }^{3}$, Nicola Bettoso ${ }^{4}$, and J. Sook Chung $^{5}$ \\ 1 Department of Life Sciences, University of Trieste, via L. Giorgieri, 5, 34127, Trieste (Trieste), Italy \\ 2 Riserva Naturale Regionale "Valle Canal Novo", via delle Valli 2, 33050, Marano Lagunare (Udine), Italy \\ 3 Civico Aquario Marino, Molo Pescheria, 2, 34123, Trieste (Trieste), Italy \\ 4 Agenzia Regionale per la Protezione dell'Ambiente del Friuli Venezia Giulia, via A. La Marmora, 13, 34139 Trieste, Italy \\ 5 Institute of Marine and Environmental Technology, University of Maryland Center for Environmental Science, 701 East Pratt Street \\ Baltimore, MD 21202, USA \\ * Corresponding author E-mail: cmanfrin@units.it
}

\begin{abstract}
Since August 2015, an increasing number of Blue Crabs, Callinectes sapidus Rathbun, 1896, have been reported in the Marano and Grado Lagoon, Gulf of Trieste, in the northern Adriatic Sea. This species is not a new introduction and in fact the first record of $C$. sapidus in Italy and the entire Adriatic Sea dates back to 1949 in the Grado Lagoon. Interestingly, no other records of $C$. sapidus have been reported since the first record. Here, we note the re-appearance of $C$. sapidus in the Gulf of Trieste.
\end{abstract}

Key words: invasive species; re-appearance; Marano and Grado Lagoon; Adriatic Sea

The American Blue Crab, Callinectes sapidus Rathbun, 1896 (Decapoda: Portunidae) is a euryhaline and eurythermal invasive species in Europe. Its native range is the western North Atlantic Ocean from Nova Scotia to Argentina. However, during the last decade, its range has expanded, either accidentally or deliberately, into both Asia and Europe (Galil 2000). The first record in Western Europe was from the Biscay Gulf, France, in the early 20th century (Bouvier 1901). Since then, this species has been reported from the North Sea (Netherlands in 1932, Belgium in 1981, and Germany in 1965) (Den Hartog and Holthuis 1951; Kühl 1965; Adema 1991; Gollasch 1996) and in the Baltic Sea in 1951 (Denmark) (Wolff 1954; Knudsen 1989; Gollasch 1996). It has been found along the coasts of Britain in 1982 (Clark 1984; Minchin et al. 2013), Portugal (Gaudêncio and Guerra 1979), and Spain (Cabal et al. 2006).

Starting in the late 1960s, C. sapidus was observed in Bulgaria (Black Sea) (Bulgurkov 1968; Petrescu et al. 2000), Russia (Azov Sea) (Diripasko et al. 2009; Pashkov et al. 2012), Ukraine (Monin 1984), and Georgia (Shaverdashvili and Ninua 1975). Records are being continuously updated, and the most recent sighting was off Turkey (Yağlıŏlu et al. 2014).

Callinectes sapidus reached the Mediterranean basin in ships' ballast tanks (Holthuis and Gottlieb 1955), but the timing is unknown (Castriota et al. 2012). This species was in fact often mistaken for Portunus segnis (Forskål, 1775 ) and often had been called Neptunus pelagicus or $P$. pelagicus (Linnaeus, 1758) until the $P$. pelagicus species complex was revised (Lai et al. 2010).

Callinectes sapidus was reported from the Ebro delta, Spain (Tuncer 2008) and Guadalquivir, southern Iberia (Cabal et al. 2006), suggesting an active expansion of range of this species toward southern latitudes in estuaries (Ribeiro and Veríssimo 2014). In the Mediterranean, C. sapidus is known from Malta (Sciberras and Schembri 2007), the Ligurian Sea (Tortonese 1965; Bisconti and Silvi 2005), the Aegian-Levantine Sea basin (Serbetis 1959; Enzenrob et al. 1997; Zaitsev and Öztürk 2001), and the Ionian Sea (Molnar et al. 2008; Thessalou-Legaki et al. 2012).

In the Adriatic Sea, C. sapidus was first recorded in 1949, as Neptunus pelagicus, from Grado Lagoon (Giordani Soika 1951). The correct identity was established in 1993 following the discovery of two males in the Venice Lagoon in 1991 and 1992 (Mizzan 1993).

Many records were reported from the Adriatic Sea, along both western (Gennaio et al. 2006; Scaravelli and Mordenti 2007; Florio et al. 2008; Castriota et al. 2012; Mancinelli 2013; Cilenti et al. 2015; Manfrin et al. 2015) and eastern coasts (Tuncer 2008; Beqiraj and Kashta 2010; Dulčić et al. 2010; Dulčić et al. 2011). However, 


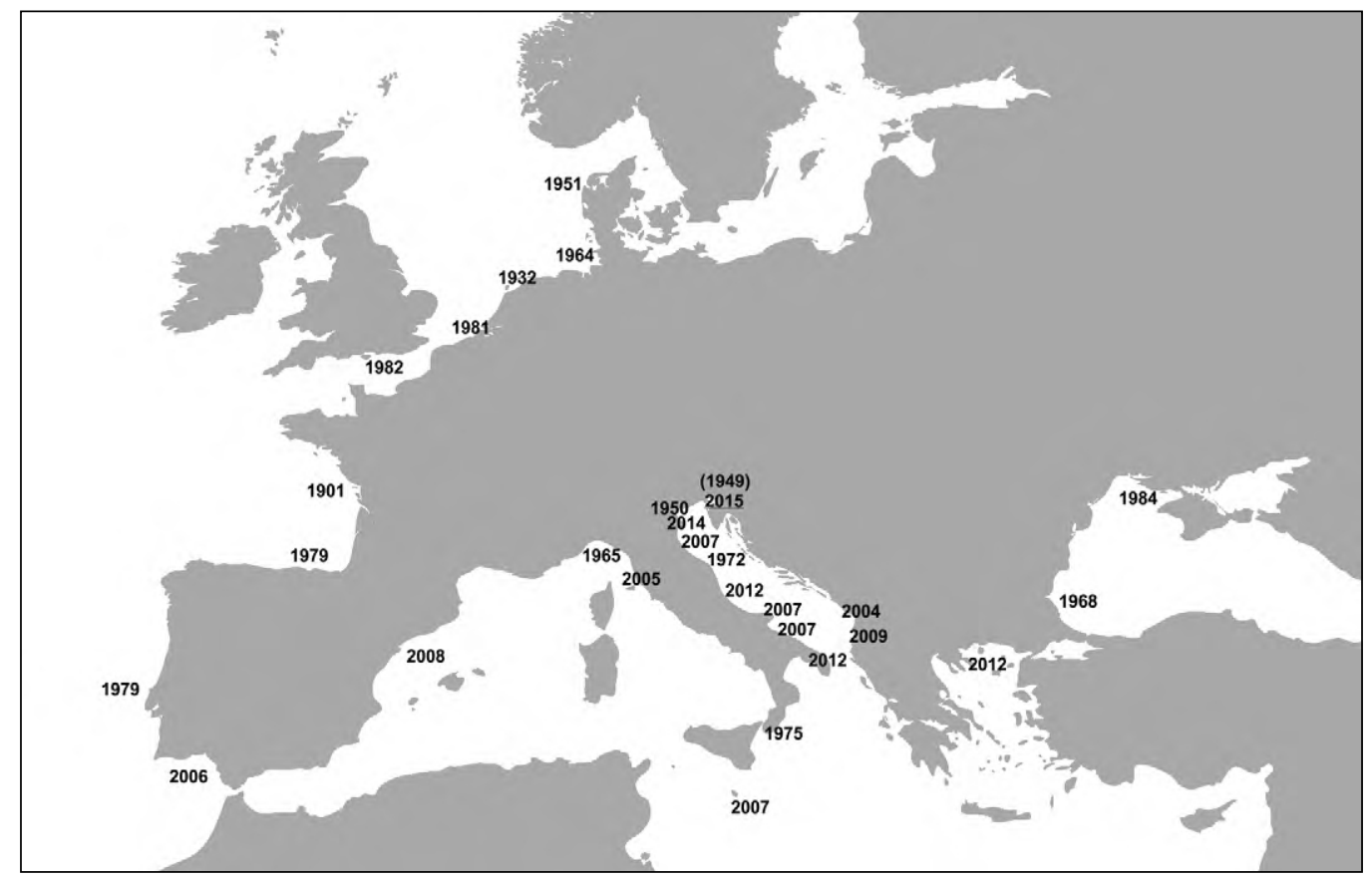

Figure 1. Locations and year of first appearance of Callinectes sapidus in Europe and Italy. The literature on which this is based is cited in the text.

no other $C$. sapidus have been collected from the Gulf of Trieste, until now. First records for $C$. sapidus in European waters are summarized in Figure 1.

Here, we document the occurrence of $C$. sapidus in the Gulf of Trieste, 66 years after the previous (and first) record from the same area (Giordani Soika 1951).

The Gulf of Trieste is divisible into two main sectors that are separated by the Timavo River. The first sector extends to the sandy Grado littoral zone at west, whereas the second sector extends from the Timavo River to the Istrian littoral and is characterized by rocky coastline. The Gulf includes the Marano and Grado Lagoon.

The Marano and Grado Lagoon is one of the most ecologically intact wetlands in the entire Mediterranean area. The lagoon complex, between the deltas of the Tagliamento and Isonzo rivers is approximately 32 $\mathrm{km}$ long, up to $5 \mathrm{~km}$ wide, and has an area of $160 \mathrm{~km}^{2}$. The surrounding drainage basin $\left(1,880 \mathrm{~km}^{2}\right)$ delivers important loads of both nutrients and pollutants (Covelli et al. 2012; Saccon et al. 2013). Since 1971, the lagoon is protected by the Ramsar Convention. Following the implementation of the Habitats Directive (92/43/EC), which concerns the protection of biodiversity, it is also identified in the state-sponsored "Natura 2000" survey as a Site of Community Importance (SCIs IT3320037). The area is economically important, supporting tourism and industry. There are recreational fisheries (mainly the Venerupis philippinarum [A.Adams \& Reeve, 1850], Manila Clam) and with fish farming (Acquavita et al. 2014). According to the Water Framework Directive 2000/60/EC, three main water types were identified in the Marano and Grado Lagoon: mesohaline TME (5-20 PSU), polyhaline TPO (20-30 PSU), and euhaline TEU (30-40 PSU) (Bettoso et al. 2010).

Five specimens of $C$. sapidus were collected between late August 2015 to September 2016 (Table 1) within the Marano and Grado Lagoon (Figure 2).

Collection of the specimens numbers $1,2,4$, and 5 (Table 1) was done using fyke nets with the help of local anglers, A fyke net consists of a barrier of about $60 \mathrm{~m}$ in length and $1.3 \mathrm{~m}$ in height, with a mesh size of $1.6 \mathrm{~cm}$, which leads fish and shrimp towards four coneshaped, unbaited traps also with the same mesh size. This fishing gear, with the barriers set perpendicular to the tidal flow, takes advantage of tidal dynamics to catch fish and shrimp (Malavasi et al. 2004). Specimen

Table 1. Collection sites of each specimen, along with date of collection, size expressed as carapace width and sex. Voucher ID ZI-06635 is within the collection of the Museo Friulano di Storia Naturale of Udine (via Sabbadini, 32, 33100, Udine, Italy), while voucher ID c485 is stored and is part of the collection of the Civico Museo di Storia Naturale of Trieste (via dei Tominz, 4, 34139, Trieste, Italy). Pictures of each specimen are reported in Figure 3.

\begin{tabular}{|c|c|c|c|c|c|c|c|}
\hline Site no. & Site & Geographic coordinates & Date collected & Carapace width (mm) & Sex & Voucher & Figure \\
\hline 1 & Marano Lagoon & $45.70^{\circ} \mathrm{N}, 013.11^{\circ} \mathrm{E}$ & 27 August 2015 & 160 & $\hat{\delta}$ & ZI-06635 & Figure $3 a$ \\
\hline 2 & Marano Lagoon & $45.70^{\circ} \mathrm{N}, 013.20^{\circ} \mathrm{E}$ & 30 September 2015 & 176 & 우 & - & Figure $3 b$ \\
\hline 3 & Grado Lagoon & $45.70^{\circ} \mathrm{N}, 013.35^{\circ} \mathrm{E}$ & 29 October 2015 & 190 & $\hat{\sigma}$ & c485 & Figure $3 c$ \\
\hline 4 & Marano Lagoon & $45.70^{\circ} \mathrm{N}, 013.08^{\circ} \mathrm{E}$ & 26 August 2016 & 177 & $\hat{0}$ & - & Figure $3 d$ \\
\hline 5 & Marano Lagoon & $45.70^{\circ} \mathrm{N}, 013.20^{\circ} \mathrm{E}$ & 9 September 2016 & 158 & $\hat{\sigma}$ & - & Figure 3e \\
\hline
\end{tabular}



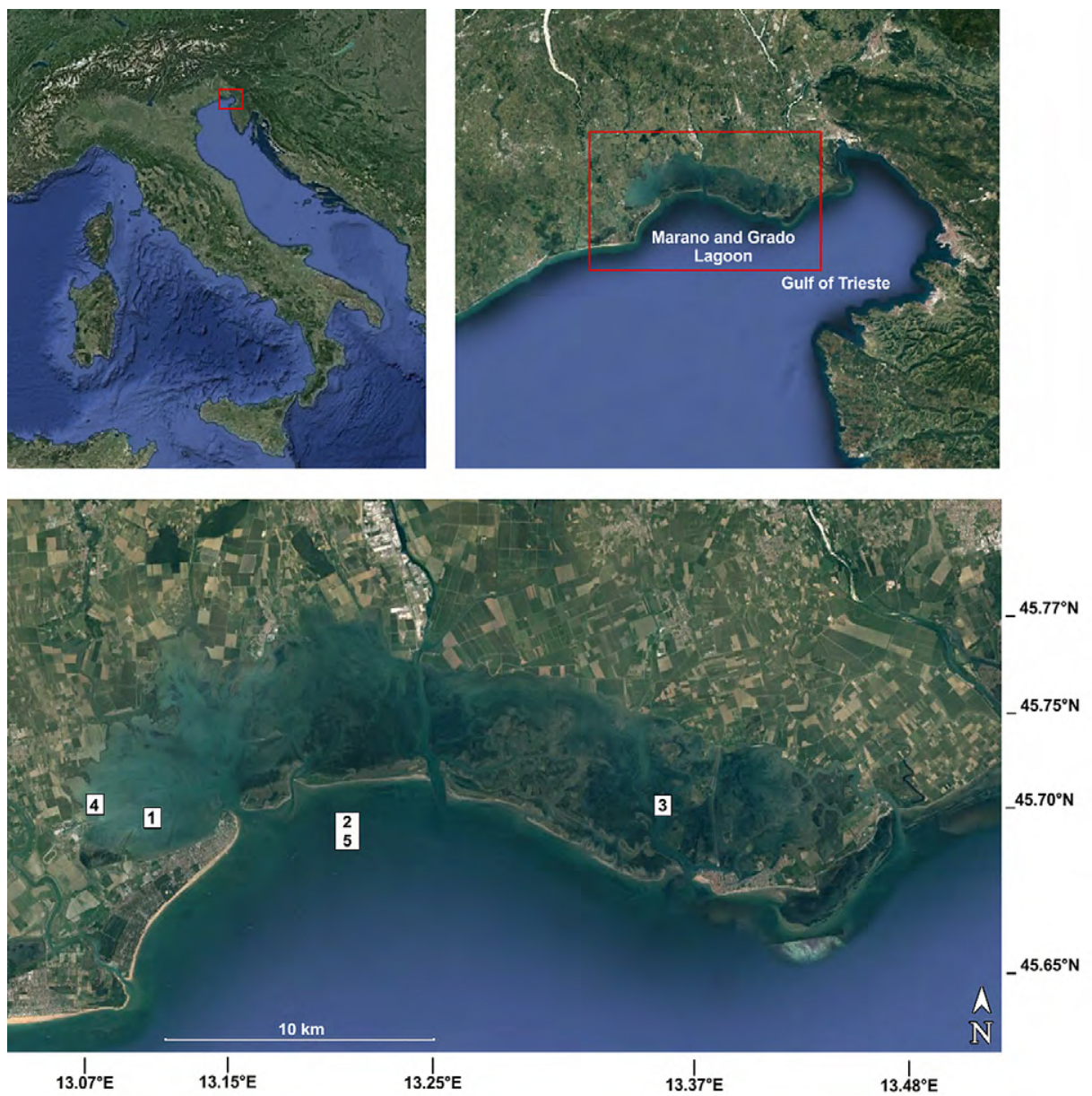

Figure 2 Map of the Gulf of Trieste showing collecting sites (white dots) for each of the five specimens (site numbers correspond to those in Table 1).

number 3 was collected in water about $4 \mathrm{~m}$ deep by mean of trammel net.

Specimens (Figure 3) were identified according to Williams (1974) and Galil et al. (2002). We identified the species in loco and later one of us (JSC) confirmed the identificiation using photographs. The carapace width (CW, maximal distance between the posterior anterolateral spines; Table1) and sex were recorded for each specimen. Callinectes sapidus is characterized by an intense blue color of the appendix. The remainder of the exoskeleton is olive-brown. As with other portunid crabs, the fifth leg is paddle-shaped, adapted for swimming. The genus Callinectes is distinguished from other portunid crabs by the lack of an internal spine on the carpus (the middle segment of the claw), as well as by the T-shape of the male abdomen (Williams 1974). Males and females of $C$. sapidus can be distinguished sexually dimorphic shape of the abdomen: males possess a structure, called the apron, shaped as a long, narrow, inverted "T" (Figure $3 c$ ), whereas in females, the apron is wider, rounded, crescent-shaped (Williams 1974).

Specimen number 1 (Figure 3a) was deposited in the Museo Friulano di Storia Naturale of Udine (ZI-06635), and specimen number 3 (Figure $3 c$ ) was deposited in the Civico Museo di Storia Naturale of Trieste (c485).
About 70 years ago one specimen of $C$. sapidus was found near Grado (Giordani Soika 1951). Subsequent to this record, no additional specimes of $C$. sapidus have been found in the Gulf of Trieste until now.

According to the Harding's (2003) classification, crabs can be divided into three size groups (small, CW < $80 \mathrm{~mm}$; medium, CW 80-120 mm; and large, CW > 120 $\mathrm{mm}$ ) and our specimens are fit the large category. All the specimens were caught in water where salinity is greater than 30. Dulčić et al. (2011) observed that populations of $C$. sapidus are partitioned by sex: males prefer more brackish water (20-25 salinity), whereas adult females tend to concentrate in higher salinity waters $(>30)$. We cannot confirm those observations by Dulčić et al. because our four male and one female specimens were collected high salinity water $(>30)$. Salinity is important for the development of this species' eggs and larvae (Costlow 1967), and therefore, adult females are expected to be more numerous in more saline environments, and they migrate further out into the coastal waters for spawning (Steele and Bert 1994; Murphy et al. 2001).

To date, no larvae have been caught in the Gulf of Trieste, based on observations exclusively of anglers who are not generally focused on larvae. We speculate that larvae are carried in ships' ballasts from other 

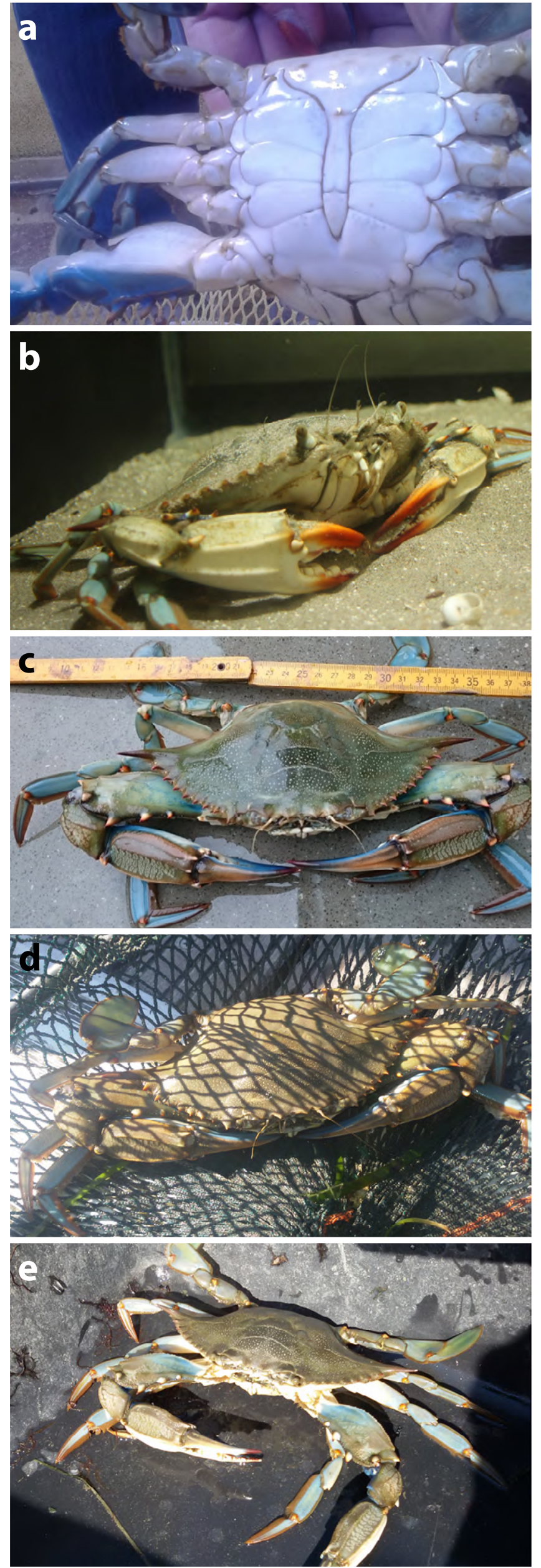

areas. Once released into the Gulf, a small number of larvae might grow to adulthood, but we do not have evidence of this at this time. We know of at least 12 adult individuals of $C$. sapidus, the five we caught and others eaten by anglers, but others may have been found by anglers. We also do not know if juveniles are present. It is possible that changes in environmental conditions may contribute to the spread and growth of $C$. sapidus in the Gulf of Trieste.

From 1949 to 2014, the mean annual temperature of the sea has increased by about $1^{\circ} \mathrm{C}$ (data not shown and personally provided by Dr. F. Raicich from Institute of Marine Sciences of the National Research Council (CNR) of Trieste). However, this increase seems not to explain our new records of $C$. sapidus because it is already established in the North Sea, where temperatures are much lower than the Adriatic. Other environmental conditions (salinity and organic load) should be considered but long-term data are not available.

Dulčić et al. (2011) and Beqiraj and Kashta (2010) gave evidence of an established population elsewhere in the Adriatic Sea (Neretva River delta, Croatia, and Patok Lagoon, Albania, respectively). Due to invasiveness of this species, the Marano and Grado Lagoon and the offshore areas could provide favorable conditions for the establishment of a population of $C$. sapidus in this area. This species is an omnivore, feeding on fishes, mollusks, crustaceans, and algae. It has a complex life history and utilizes both marine and estuarine habitats (Hines et al. 1987).

The Marano and Grado Lagoon is among the most important areas in Italy for Manila clam production, and in 2010, production was 1,042 tons (Sladonja et al. 2011). The Marano and Grado Lagoon also represents an important habitat for fish and a nursery ground for juveniles. The lagoon hosts the two most important ports, Marano Lagunare and Grado, for fisheries in the Friuli Venezia Giulia region (Bettoso et al. 2013).

Thus, a significant increase of $C$. sapidus might have severe consequences for the autochthonous ecological communities, as well as for the shellfish farms and artisanal fishery, by preying on bivalves and damaging fish nets, pots, and the fish caught inside. On the other hand, C. sapidus is considered a delicacy and is harvested not only as hard-shell crabs but also as peeler crabs just prior to molting and soft-shell crabs immediately after molting. The large consumption of $C$. sapidus in North America and Europe, as well as Japan, is supplied by major commercial fisheries (Branco and Fracasso 2004). Therefore, $C$. sapidus should be promoted as a new food source locally and might reduce its potential negative impacts on the indigenous fauna (Dulčić et al. 2011; Župan et al. 2016).

Figure 3. Callinectes sapidus from the Marano and Grado Lagoon. Morphometric and other information on each animal are reported in the Table 1. 
It is paramount that the presence, establishment, and abundance of $C$. sapidus populations be monitored so that the potential impacts of this alien species on the biodiversity of the region, as well on bivalve production, are known. Globally, the second most serious threat to biodiversity is invasive species (Genovesi 2002); only habitat loss and fragmentation is more serious (Florio et al. 2008). Efforts to constantly update new invasive decapod species in the Marano and Grado Lagoon, such as Palaemon macrodactylus Rathbun, 1902 (Cuesta et al. 2014) and Eriocheir sinensis H. Milne-Edwards, 1853 (Bettoso and Comisso 2015), are useful information for management and conservation plans. More introductions of invasive species into the Mediterranean are expected in the coming years, especially with the recent expansion of the Suez Canal. Continuous monitoring and updates are needed to assess, whether the presence of $C$. sapidus is random and incidental, as in the case happened in 1949, or if a population, even small, of $C$. sapidus is being established. The propagule pressure (Lockwood et al. 2005) it is not known and the framework of the invasion is under observation, it could putatively be between $\mathrm{C} 1$ and $\mathrm{C} 3$ category of the unified framework for biological invasions (Blackburn et al. 2011). In addition, the Gulf of Trieste is an important site for mollusk's production, and the impact of blue crabs on the local clam population and production should be evaluated.

\section{ACKNOWLEDGEMENTS}

We thank Dr. Saul Ciriaco of the Riserva Naturale di Miramare of Trieste and Prof Piero G. Giulianini of the University of Trieste for their support, as well as Dr. Fabio Raicich from the Institute of Marine Sciences of the National Research Council (CNR) of Trieste for the providing the sea temperature data and to Alessandro D'Aietti of the Agenzia Regionale per la Protezione dell'Ambiente del Friuli Venezia Giulia for his support with georeferencing. Thanks go to the angler Gianpietro Corso, who contacted us to report the presence of $C$. sapidus in the Marano and Grado Lagoon.

\section{LITERATURE CITED}

Acquavita, A., J. Falomo, S. Predonzani, F. Tamberlich, N. Bettoso and G. Mattassi. 2014. The PAH level, distribution and composition in surface sediments from a Mediterranean Lagoon: the Marano and Grado Lagoon (northern Adriatic Sea, Italy). Marine Pollution Bulletin 81(1): 234-241. doi: 10.1016/j.marpolbul.2014.01.041

Adema, J. 1991. De krabben van Nederland en Belgie (Crustacea, Decapoda, Brachyura). Leiden: Nationaal Natuurhistorisch Museum. 244 pp.

Beqiraj, S. and L. Kashta. 2010. The establishment of Blue Crab Callinectes sapidus Rathbun, 1896 in the Lagoon of Patok, Albania (south-east Adriatic Sea). Aquatic Invasions 5(2): 219-221. doi: 10.3391/ai.2010.5.2.16

Bettoso, N., I.F. Aleffi, L. Faresi, P. Rossin, G. Mattassi and P. Crivellaro. 2010. Evaluation on the ecological status of the macrozoobenthic communities in the Marano and Grado Lagoon (northern Adriatic Sea). Annales, Series Historia Naturalis 20(2): 193-206.

Bettoso, N., A. Acquavita, A. D’Aietti and G. Mattassi. 2013. The Marano and Grado Lagoon: a brief synopsis on the aquatic fauna and fisheries resources. Annales, Series Historia Naturalis 23: 135-142.

Bettoso, N. and G. Comisso. 2015. First record of the Chinese Mitten Crab (Eriocheir sinensis) in the Lagoon of Marano and Grado (northern Adriatic Sea). Annales Series Historia Naturalis 25: 29-34.

Bisconti, M. and E. Silvi. 2005. Prima segnalazione di Callinectes sapidus Rathbun, 1896 (Crustacea, Decapoda, Brachyura) nella provincia di Livorno. Quaderni del Museo Provinciale di Storia Naturale di Livorno 18: 1-6.

Bizjak, P. 2007. Allevamento in concessione di molluschi bivalvi nella Laguna di Marano e Grado ai sensi del regolamento attuativo della L. R. n. 31/2005; pp. 132-137, in: Linee guida e casi di studio per la gestione dei siti della rete Natura 2000 in ambiente di transizione : atti del workshop tenutosi a Grado, Palazzo dei congressi, 7-8 giugno 2006. Trieste: EUT Edizioni Università di Trieste.

Bouvier, E. 1901. Sur un Callinectes sapidus M. Rathbun trouvé à Rochefort (on Callinectes sapidus M. Rathbun found in Rochefort). Bulletin du Muséum d'Histoire Naturelle (7): 16.

Branco, J.O. and H.A.A. Fracasso. 2004. Biologia populacional de Callinectes ornatus (Ordway) na Armação do Itapocory, Penha, Santa Catarina, Brasil. Revista Brasileira de Zoologia. 21: 91-96. doi: 10.1590/S0101-81752004000100016

Bulgurkov, K.I. 1968. Callinectes sapidus Rathbun in the Black Sea. Izvest. Niors. 9: 97-99.

Cabal, J., Pis Millán, J.A.P. and J.C. Arronte. 2006. A new record of Callinectes sapidus Rathbun, 1896 (Crustacea: Decapoda: Brachyura) from the Cantabrian Sea, Bay of Biscay, Spain. Aquatic Invasion 1(3): 186-187. doi: 10.3391/ai.2006.1.3.14

Castriota, L., F. Andaloro, R. Costantini and A. De Ascentiis. 2012. First record of the Atlantic crab Callinectes sapidus Rathbun, 1896 (Crustacea: Brachyura: Portunidae) in Abruzzi waters, central Adriatic Sea. Acta Adriatica 53(3): 467-470.

Cilenti, L., G. Pazienza, T. Scirocco, A. Fabbrocini and R. D’Adamo. 2015. First record of ovigerous Callinectes sapidus (Rathbun, 1896) in the Gargano Lagoons (south-west Adriatic Sea). BioInvasions Records 4(4): 281-287. doi: 10.3391/bir.2015.4.4.09

Clark, P.F. 1984. Recent records of alien crabs in Britain. Naturalist 109: 111-112.

Costlow, J.D.j. 1967. The effect of salinity and temperature on survival and metamorphosis of megalops of the blue crab Callinectes sapidus. Helgoländer Wissenschaftliche Meeresuntersuchungen15(1-4): 84-97. doi 10.1007/BF01618611

Covelli, S., L. Langone, A. Acquavita, R. Piani and A. Emili. 2012. Historical flux of mercury associated with mining and industrial sources in the Marano \& Grado Lagoon (northern Adriatic Sea). Estuarine, Coastal and Shelf Science 113: 7-19. doi: 10.1016/j. ecss.2011.12.038

Cuesta, J.A., N. Bettoso, G. Comisso, C. Froglia, G. Mazza, A. Rinaldi, A. Rodriguez and T. Scovacricchi. 2014. Record of an established population of Palaemon macrodactylus Rathbun, 1902 (Decapoda, Palaemonidae) in the Mediterranean Sea: confirming a prediction. Mediterranean Marine Science 15(3): 569-573. doi: 10.12681/mms.712

Den Hartog, C. and L.B. Holthuis. 1951. De Noord-Americaanske "Blue Crab" in Nederland. De Levende Natur 54: 121-125. http://natuurtijdschriften.nl/download?type=document;do cid=492835

Diripasko, O.A., L.V. Izergin and A.I. Koshkalda. 2009. First finds of the Blue Crab Callinectes sapidus (Portunidae, Decapoda) in 
the Sea of Azov. Vestnik Zoologii 43(6): 529-532.

Dulčić, J., B. Dragičević and L. Lipej. 2010. New record of the Blue Crab, Callinectes sapidus Rathbun, 1896, (Decapoda: Brachyura) in the Adriatic Sea. Annales Series Historia Naturalis 20: 23-28.

Dulčić, J., P. Tutman, S. Matic-Skoko and B. Glamuzina. 2011. Six years from first record to population establishment: the case of the Blue Crab, Callinectes sapidus Rathbun, 1896 (Brachyura, Portunidae) in the Neretva River delta (south-eastern Adriatic Sea, Croatia). Crustaceana 84(10): 1211-1220. doi: 10.1163/156854011X587478

Enzenrob, R., L. Enzenrob and F. Bingel. 1997. Occurrence of Blue Crab, Callinectes sapidus (Rathbone, 1896) (Crustacea, Brachyura) on the Turkish Mediterranean and the adjacent Aegean coast and its size distribution in the Bay of Iskenderun. Journal of Turkish Zoology 21: 113-122.

Florio, M., P. Breber, T. Scirocco, A. Specchiulli, L. Cilenti and L. Lumare. 2008. Exotic species in Lesina and Varano lakes new guest in Lesina and Varao lakes: Gargano National Park (Italy). Transitional Waters Bulletin 2: 69-79.

Galil, B., C. Froglia and P. Noël. 2002. CIESM atlas of exotic species in the Mediterranean; pp. 192, in: F. Briand (ed.). Crustaceans: decapods and stomatopods. Monaco: CIESM Publishers.

Gaudêncio, M.J. and M.T. Guerra. 1979. Note sur la presence de Callinectes sapidus Rathbun 1896 (Crustacea Decapoda Brachyura) dans l'estuaire du Taje. Boletim do Instituto Nacional de Investigação das Pescas 2: 67-73.

Gennaio, R., G. Scordella and M. Pastore. 2006. Occurrence of Blue Crab Callinectes Sapidus (Rathbun, 1986, Crustacea, Brachyura), in the Ugento ponds area (Lecce, Italy). Thalassia Salentina 29: 29-39.

Genovesi, P. 2002. Introduzioni biologiche: impatto sulla biodiversità e priorità di azione per il futuro; pp. 75-80, in: Atti del Convegno Nazionale "La gestione delle specie alloctone in Italia. Il caso della nutria e del gambero rosso della Louisiana", Firenze, 24-25 Ottobre

Giordani Soika, A. 1951. Il Neptunus pelagicus (L.) nell'Alto Adriatico. Natura 42: 18-20.

Gollasch, S. 1996. Untersuchungen des Arteintrages durch den internationalen Schiffsverkehr unter besonderer Berücksichtigung nichtheimischer Arten [dissertation], Hamburg: University of Hamburg/ Verlag Dr. Kovac. 314 pp.

Harding, J.M. 2003. Predation by Blue Crabs, Callinectes sapidus, on Rapa Whelks, Rapana venosa; possible natural controls for an invasive species? Journal of Experimental Marine Biology and Ecology 297: 161-177.

Hines, A.H., R.N. Lipcius and A.M. Haddon. 1987. Population dynamics and habitat partioning by size, sexes and moult stage of blue crabs Callinectes sapidus in a subestuary of central Chesapeake Bay. Marine Ecology Progressive Series 36: 55-64.

Holthuis, L.B. and E. Gottlieb. 1955. The occurrence of the American Blue Crab, Callinectes sapidus Rath. Israel waters. Bulletin of the Research Council of Israel 5B(2): 155-156.

Knudsen, J. 1989. Immigration of marine invertebrates to the Limford (Denmark) in the North Sea-Baltic transition area; pp. 135-145, in: E. Spainer, Y. Steinberger and M. Luria (eds.). Environmental quality and ecosystem stability. Jerusalem, ISEEQ Publication.

Kühl, H. 1965. Fang einer Blaukrabbe, Callinectes sapidus Rathbun (Crustacea, Portunidae) in der Elbmündung. Archiv für Fischereiwissenschaften 15: 225-227.

Lai, J.C.Y., P.K.L. Ng and P.J.F. Davie. 2010. A revision of the Portunus pelagicus (Linnaeus, 1758) species complex (Crustacea: Brachyura: Portunidae), with the recognition of four species. The Raffles Bulletin of Zoology 58(2): 199-237.

Malavasi, S., R. Fiorin, A. Franco, P. Franzoi, A. Granzotto, F. Riccato and D. Mainardi. 2004. Fish assemblages of Venice Lagoon shallow waters: an analysis based on species, families and functional guilds. Journal of Marine Systems 51: 19-31. doi: 10.1016/j.jmarsys.2004.05.006

Mancinelli, G., L. Carrozzo, M.L. Costantini, L. Rossi, G. Marini and M. Pinna. 2013. Occurrence of the Atlantic Blue Crab Callinectes sapidus Rathbun, 1896 in two Mediterranean coastal habitats: temporary visitor or permanent resident? Estuarine, Coastal and Shelf Science 135: 46-56.

Manfrin, C., E. Turolla, J.S. Chung and P.G. Giulianini. 2015. First occurrence of Callinectes sapidus (Rathbun, 1896) within the Sacca di Goro (Italy) and surroundings. Check List 11(3): 1640. doi: 10.15560/11.3.1640

Minchin, D., E. Cook and P.F. Clark. 2013. Alien species in British brackish and marine waters. Aquatic Invasions 8(1): 3-19. doi: 10.3391/ai.2013.8.1.02

Mizzan, L. 1993. Presence of swimming crabs of the genus Callinectes (Stimpson) (Decapoda, Portunidae) in the Venice Lagoon (North Adriatic Sea, Italy). Bulletin of the Natural History Museum of Venice 42: 31-43.

Molnar, J.L., R.L. Gamboa, C. Revenga and M.D. Spalding. 2008. Assessing the global threat of invasive species to marine biodiversity. Frontiers in Ecology and the Environment 6(9): 485-492. doi: 10.1890/070064

Monin, V.L. 1984. A new record of Blue Crab Callinectes sapidus (Decapoda Brachiura) in the Black Sea. Zoologicheskii Zhurnal 63(7): 1100-1102.

Murphy, M.D., C.A. Meyer and A.L. McMillen-Jackson. 2001. A stock assessment for blue crab, Callinectes sapidus, in Florida waters. Report to the Florida Fish and Wildlife Commission, Division of Marine Fisheries. Florida Fish and Wildlife Conservation Commission, Florida Marine Research Institute. St. Petersburg, Florida.

Pashkov, A.N., S.I. Reshetnikov and K.B. Bondarev. 2012. The capture of the Blue Crab (Callinectes sapidus, Decapoda, Crustacea) in the Russian sector of the Black Sea. Russian Journal of Biological Invasions 3(1): 22-28. doi: 10.1134/S2075111712010067

Petrescu, I., N. Papadopol and S. Nicolaev. 2000. O nouã specie pentru fauna de decapode din apele marine româneşti, Callinectes sapidus Rathbun, 1896. Analele Universității "Ovidius" Constanța, Seria Biologie-Ecologie 4: 222-227.

Ribeiro, F. and A. Veríssimo. 2014. A new record of Callinectes sapidus in a western European estuary (Portuguese coast). Marine Biodiversity Records 7: e36. doi: 10.1017/S1755267214000384

Saccon, P., A. Leis, A. Marca, J. Kaiser, L. Campisi, M.E. Bootcher, J. Savarino, P. Escher, A. Eisenhauer and J. Erbland. 2013. Multiisotope approach for the identification and characterisation of nitrate pollution sources in the Marano Lagoon (Italy) and parts of its catchment area. Applied Geochemistry 34: 75-89. doi: 10.1016/j.apgeochem.2013.02.007

Scaravelli, D. and O. Mordenti. 2007. Segnalazioni Faunistiche. Quaderno di studi e notizie di storia naturale della Romagna 24: 155-160.

Sciberras, M. and P. Schembri. 2007. A critical review of records of alien marine species from the Maltese Islands and surrounding waters (central Mediterranean). Mediterranean Marine Science 8(1): 41-66. doi: 10.12681/mms.162

Serbetis, C. 1959. Un nouveau crustacé commestible en mer Egeé Callinectes sapidus Rath. (Decapod. Brach.). Proceedings of the General Council and Fisheries Commission of the Mediterranean. 5: 505-507.

Shaverdashvili, R.S. and N.S. Ninua. 1975. New find of crab Callinectes sapidus Rathbun, 1896 in the Black Sea. Nauchnyye Doklady Vysshey Shkoly 9: 19-20.

Sladonja, B., N. Bettoso, A. Zentilin, F. Tamberlich and A. Acquavita. 2011. Manila Clam (Tapes philippinarum Adams \& Reeve, 1852) in the Lagoon of Marano and Grado (northern Adriatic Sea, Italy): 
socio-economic and environmental pathway of a shell farm; 24 pp., in: B. Sladonja (ed.). Aquaculture and the environment-a shared destiny. Rijeka: InTech. doi: 10.5772/31737

Steele, P. and T.M. Bert. 1994. Population ecology of the Blue Crab, Callinectes sapidus Rathbun, in a subtropical estuary: population structure, aspects of reproduction and habitat partitioning. Florida Marine Research Institute Publication 51: 1-24.

Thessalou-Legaki, M., O. Aydogan, P. Bekas, G. Bilge, Y. Boyaci, E. Brunelli, V. Circosta, F. Crocetta, F. Durucan, M. Erdem, A. Ergolavou, H. Filiz, F. Fois, E. Gouva, K. Kapiris, S. Katsanevakis, Z. Kljajic, E. Konstantinidis, G. Konstantinou, D. Koutsogiannopoulos, S. Lamon, V. Macic, R. Mazzette, D. Meloni, A. Mureddu, I. Paschos, C. Perdikaris, F. Piras, D. Poursanidis, A. Ramos-Espla, A. Rosso, P. Sordino, E. Sperone, A. Sterioti, E. Taskin, F. Toscano, S. Tripepi, L. Tsiakkiros and A. Zenetos. 2012. New Mediterranean biodiversity records. Mediterranean Marine Science 13(2): 312-327. http://www.medit-mar-sc.net/index.php/marine/ article/view/737

Tortonese, E. 1965. La comparsa di Callinectes sapidus Rath. (Decapoda, Brachyura) nel Mar Ligure. Annali del Museo Civico di Storia Naturale di Genova - Doriana 4(165): 1-3.

Tuncer, S., Bilgin, S 2008. First record of Callinectes sapidus Rathbun, 1896 (Crustacea: Decapoda: Brachyura) in the Dardanelles, Canakkale, Turkey. Aquatic Invasions 3(4): 469. doi: 10.3391/ ai.2008.3.4.19
Williams, A.B. 1974. The swimming crabs of the genus Callinectes (Decapoda: Portunidae). Fishery Bulletin 72: 685-798.

Wolff, T. 1954. Occurrence of two east American species of crabs in European waters. Nature 174(4421): 188-189. doi: 10.1038/ 174188a0

Yağlıoğlu, D., C. Turan and T. Öğreden. 2014. First record of Blue Crab Callinectes sapidus (Rathbun 1896) (Crustacea, Brachyura, Portunidae) from the Turkish Black Sea coast. Journal of Black Sea/Mediterranean Environment 20(1): 13-17.

Zaitsev, Y.P. and B. Öztürk. 2001. Exotic species in the Aegean, Marmara, Black, Azov and Caspian seas. Istanbul: Turkish Marine Research Foundation 20 pp.

Župan, I., A. Karaga, T. Šarić and D. Kanski. 2016. Blue Crab Callinectes sapidus Rathbun, 1896 continues invasion: first case of entering into freshwater ecosystem in the Mediterranean (Nature Park Vransko Lake, Adriatic Sea). Cahiers de Biologie Marine. 57: 81-84.

Author contributions: $C M$ conceived the manuscript; $C M, G C, A A$, $\mathrm{NB}$, and JSC made the identifications and wrote the manuscript.

Received: 17 March 2016

Accepted: 21 October 2016

Academic editor: Felipe Bezerra Ribeiro 